\title{
PERIODIC SOLUTIONS OF LIÉNARD EQUATION WITH ONE OR TWO WEAK SINGULARITIES
}

\section{AleXAnder GutiérRez AND PEDRo J. TORRES}

Abstract. In this paper we study the existence and asymptotic stability of periodic solutions of the differential equation

$$
\ddot{x}+f(x) \dot{x}+g(x)=h(t),
$$

where $h(t)$ is $T$-periodic, $f(x)$ is positive and $g(x)$ is strictly monotonically increasing and has one or two weak singularities. The method of proof relies on the construction of a positively invariant region of the flux.

Mathematics subject classification (2010): 34C25.

Keywords and phrases: periodic solution, singularity, asymptotic stability.

\section{REFERENCES}

[1] J. ChU AND P. J. ToRres, Applications of Schauder's fixed point theorem to singular differential equations, Bull. Lond. Math. Soc., 39, 4 (2007), 653-660.

[2] L. DeRwiduÉ, Systèmes différerentiels non linéaires ayant des solutions périodiques, Acad. Roy. Belg. Bull. Cl. Sci., 49 (1963), 11-32.

[3] R. FAuré, Solutions priodiques d'q́uations différentielles et méthode de Leray-Schauder. (Cas des vibrations forcées), Ann. Inst. Fourier (Grenoble), 14 (1964), 195-204.

[4] N. Forbat And A. Huaux, Détermination approchée et stabilité locale de la solution périodique d'une équation différentielle non linéaire, Mém. Publ. Soc. Sci. Arts Lett. Hainaut, 76 (1962), 193 203.

[5] A. Huaux, Sur l'existence d'une solution périodique de l'équation différentielle non linéaire $x^{\prime \prime}+$ $0,2 x^{\prime}+x /(1-x)=(0,5) \cos \omega t$, Bull. Cl. Sciences Acad. R. Belguique, 48, 5 (1962), 494-504.

[6] P. HABETS AND L. SANChez, Periodic solutions of some Liénard equations with singularities, Proc. Amer. Math. Soc., 109, 4 (1990), 1035-1044.

[7] A. C. Lazer AND S. Solimini, On periodic solutions of nonlinear differential equations with singularities, Proc. Amer. Math. Soc., 99, 1 (1987), 109-114.

[8] R. F. MARTINS, Existence of periodic solutions for second-order differential equations with singularities and the strong force condition, J. Math. Anal. Appl., 317, 1 (2006), 1-13.

[9] J. MAWHIN, Topological degree and boundary value problems for nonlinear differential equations, Topological methods for ordinary differential equations (Montecatini Terme, 1991), 74-142, Lecture Notes in Math., 1537, Springer, Berlin, 1993.

[10] M. NAGUmo, On the periodic solution of an ordinary differential equation of second order, Zenkoku Shijou Suugaku Danwakai, (1944), 54-61 (in japanese), English translation in Mitio Nagumo collected papers, Springer-Verlag, 1993.

[11] F.I. NJOKU AND P. OMARI, Stability properties of periodic solutions of a Duffing equation in the presence of lower and upper solutions, Appl. Math. Comput., 135, (2003), 471-490.

[12] I. RAChŮnKová, S. STANĔK AND M. TVRDÝ, Singularities and Laplacians in boundary value problems for nonlinear ordinary differential equations, Handbook of differential equations: ordinary differential equations. Vol. III, 607-722, Handb. Differ. Equ., Elsevier/North-Holland, Amsterdam, 2006. 
[13] I. RAChŮNKOVÁ, S. STANĚK AND M. TVRDÝ, Solvability of Nonlinear Singular Problems for Ordinary Differential Equations, Contemporary Mathematics and Its Applications, 5, Hindawi Publishing Corporation, New York, 2008.

[14] I. RACHŮNKOVÁ, M. TVRDÝ AND I. VRKOČ, Existence of nonnegative and nonpositive solutions for second-order periodic boundary-value problems, J. Differential Equations, 176, 2 (2001), 445-469.

[15] P. J. TORRES, Existence of one-signed periodic solutions of some second-order differential equations via a Krasnoselskii fixed point theorem, J. Differential Equations, 190, 2 (2003), 643-662.

[16] P. J. TORRES, Weak singularities may help periodic solutions to exist, J. Differential Equations, 232, 1 (2007), 277-284.

[17] P. J. TORRES, Existence and stability of periodic solutions for second-order semilinear differential equations with a singular nonlinearity, Proc. Roy. Soc. Edinburgh Sect. A, 137, 1 (2007), 195-201.

[18] Z. ZHANG AND R. YUAN, Existence of positive periodic solutions for the Liénard differential equations with weakly repulsive singularity, Acta Appl. Math., 111, 2 (2010), 171-178.

[19] A. ZITAN AND R. ORTEGA, Existence of asymptotically stable periodic solutions of a forced equation of Liénard type, Nonlinear Anal., 22 (1994), 993-1003. 